https://helda.helsinki.fi

\title{
Third country effects of fiscal devaluations
}

\section{Engler, Philipp}

2018-02

Engler, P , Pasch , S \& Tervala, J V S 2018 , ' Third country effects of fiscal devaluations ' , Economics Letters, vol. 163 , pp. 13-16 . https://doi.org/10.1016/j.econlet.2017.11.011

http://hdl.handle.net/10138/232705

https://doi.org/10.1016/j.econlet.2017.11.011

acceptedVersion

Downloaded from Helda, University of Helsinki institutional repository.

This is an electronic reprint of the original article.

This reprint may differ from the original in pagination and typographic detail.

Please cite the original version. 


\title{
Third country effects of fiscal devaluations
}

\author{
Philipp Engler, Sandra Pasch and Juha Tervala
}

\begin{abstract}
We analyse fiscal devaluation in a three-country model. The introduction of the third country, outside a monetary union, increases the expansionary effect of fiscal devaluation and the second country of the monetary union experiences a boom instead of a recession.
\end{abstract}

Keywords: Fiscal devaluation, fiscal policy, monetary union, current account, 3country model

JEL Classification Numbers: E32, E62, F32, F41 


\section{Introduction}

Fiscal devaluations have been discussed in the recent literature as an alternative macroeconomic stabilization tool to a depreciation of the nominal exchange rate for countries in a monetary union (MU). ${ }^{1}$ With the exchange rate fixed vis-à-vis their MU partner countries, a country-specific recession can be mitigated and a current account deficit be reduced by a reduction of the social security contribution (SSC) rate and an offsetting increase of the value-added tax (VAT) rate that makes the policy revenue neutral. So far, this policy has been intensively analysed in calibrated small open economy or 2-country models of a MU. What has been missing so far, and what this paper contributes, is an explicit analysis of repercussions of a third country outside the MU.

Engler et al. (2017, henceforth EGTV) have shown in a New Keynesian DSGE model of a 2-country MU calibrated to the Eurozone (with a "core" and a "periphery" country, the latter conducting a fiscal devaluation) that if SSC paid by employers are reduced and if nominal wages are sufficiently rigid, firms' real marginal costs of production and inflation decline and the terms of trade deteriorate. The MU's central bank reacts by reducing the real rates of interest boosting consumption, net exports and output in the fiscally depreciating country. The trade balance relative to GDP rises slightly. In contrast, the core suffers from a recession because of a fall in net exports.

In this paper, we add a third country outside the MU with a flexible exchange rate to the model of EGTV. This extension increases the expansionary effects on output in the fiscally depreciating country by 10 basis points in the peak to $1.33 \%$ while the core, rather than suffering from a recession, experiences a small expansion of $0.13 \%$. From the perspective of the $\mathrm{MU}$, and in contrast to the finding of EGTV, fiscal devaluations are thus a free lunch regarding the output effects. Furthermore, the MU's trade is further boosted: In the periphery, net exports increase more while the core country's net exports decline by almost 70\% less. The conclusion drawn in EGTV that fiscal devaluations are an inadequate tool to reverse trade imbalances is thus slightly weakened with respect to the periphery but strengthened with respect to the core.

\section{The model}

In this section, we provide a brief overview of the model. The details and the parametrization are relegated to the appendix. The analysis is based on a New Keynesian DSGE model of the world economy that is normalized to size 1 consisting of two countries forming a MU and a third country whose currency is floating vis-à-vis the monetary union's currency. We denote those countries

\footnotetext{
${ }^{1}$ See Engler et al. (2017), Farhi et al. (2014), Gomes et al. (2016), Hohberger and Kraus (2016) for journal publications and Bank of Portugal (2011), Boscá et al. (2012), CPB (2013), Lipinska and von Thadden (2012) and de Mooij and Keen (2013) for working papers and book chapters.
} 
"periphery", "core", and "rest of the world", their relative sizes are $n, m-n$ and $1-m$ respectively with $n, m \in[0,1]$. The economies are populated by representative households who derive (dis-)utility from consumption, $C_{t}$, and hours worked, $N_{t}$. In the periphery ${ }^{2}$, this is $U_{t}=\mathbb{E}_{t} \sum_{s=0}^{\infty} \beta^{s}\left[\log C_{t+s}-\right.$ $\left.\left(N_{t+s}\right)^{1+\phi} /(1+\phi)\right]$, with rational expectations operator $\mathbb{E}_{t}$ and preference parameters $\beta$ and $\phi$. Households face the budget constraint

$$
\left(1+\tau_{t}^{V A T}\right) P_{t} C_{t}+B_{t}^{\text {Core }}+E_{t} B_{t}^{R o W}=R_{t-1}^{M U} B_{t-1}^{\text {Core }}+R_{t-1}^{R o W} E_{t} B_{t-1}^{R o W}+W_{t} N_{t}+\Pi_{t}+T_{t},
$$

where $\tau_{t}^{V A T}$ is the (country-specific) VAT rate that applies to all goods consumed within the country, $P_{t}$ the consumer price level, $B_{t}^{\text {Core }}$ and $B_{t}^{R o W}$ are, respectively, bonds issued by core and rest of the world households and held by the periphery household, $E_{t}$ is the nominal exchange rate between the $M U$ and the rest of the world, $R_{t-1}^{M U}$ and $R_{t-1}^{R o W}$ are the nominal interest rates set by the respective central banks, $W_{t}$ is the nominal wage, $\Pi_{t}$ are firms' profits and $T_{t}$ are lump-sum transfers.

Aggregate consumption of the periphery, $C_{t}$, is the following:

$$
C_{t}=\left[\omega \frac{1}{\sigma} C_{P e r, t}^{\frac{\sigma-1}{\sigma}}+(\varpi-\omega)^{\frac{1}{\sigma}} C_{\text {Core }, t}^{\frac{\sigma-1}{\sigma}}+(1-\varpi)^{\frac{1}{\sigma}} C_{R o W, t}^{\frac{\sigma-1}{\sigma}}\right]^{\frac{\sigma}{\sigma-1}},
$$

where $C_{P e r, t}, C_{\text {Core }, t}$ and $C_{R o W, t}$ are indexes of the periphery's, the core's and the rest of the world's goods, $\omega$ is the share of the periphery's goods in the periphery's consumption, $\varpi-\omega$ is the share of the core's goods, $1-\varpi$ is the share of the rest of the world's goods and $\sigma$ is the (Armington) elasticity of substitution between goods produced in different countries. Households allocate aggregate consumption intertemporally by an Euler equation while wages and employment are determined by trade unions that take account of the household's marginal rate of substitution (see Erceg et al., 2000).

The continuum of firms is indexed with $i$ which produce output, $Y_{t}(i)$, with labor as the only factor input according to the linear production function $Y_{t}(i)=N_{t}(i)$. Therefore, each firm $i$ combines differentiated labor, supplied by households and indexed with $z$, to an aggregate labor input $N_{t}(i)$ used in the production of good $i$ and pay wages set by monopolistically competitive unions. Firms themselves operate under monopolistic competition, both prices and wages are set in a staggered fashion a la Calvo (1983). Firms pay country specific distortionary SSC, $\tau_{t}^{S S C}$, on wages so that their profits, $\Pi_{t}(i)=P_{t}(i) Y_{t}(i)-\left(1+\tau_{t}^{S S C}\right) \int_{0}^{n} W_{t}(z) N_{t}(i, z) d z$, are directly affected by the SSC rate.

Tax revenues from the VAT and SSC are rebated to households in the form of lump-sum transfers so that the government budget constraint $T_{t}=\tau_{t}^{V A T} P_{t} C_{t}+\tau_{t}^{S S C} W_{t} N_{t}$ holds. The VAT- and SSC-rate changes in the periphery are implemented by zero mean, unanticipated "shocks" $\varepsilon_{t}^{V A T}$ and $\varepsilon_{t}^{S S C}$ and

${ }^{2}$ Core and RoW are described by according equations. 
follow $A R(1)$-processes in the (absolute) deviations from their steady state values (indicated by hats, i.e. ${\widehat{\tau_{t}}}^{V A T}$ and ${\widehat{\tau_{t}}}^{S C R}$ respectively), ${\widehat{\tau_{t}}}^{j}=\rho^{j}{\widehat{\tau_{t-1}}}^{j}+\varepsilon_{t}^{j}$ with $j=V A T, S S C$ and $\rho^{j} \in[0,1]$. A fiscal devaluation is calibrated as an unanticipated highly persistent (de facto permanent) reduction of the periphery country's SSC rate that reduces revenues worth one percent of its ex-post GDP which is exactly offset by an increase in the VAT rate. Central banks set nominal interest rates proportional to the consumer price inflation and to past interest rates.

The parameters of the model are set to mimic the "Eurozone periphery" (Greece, Italy, Ireland, Portugal and Spain) that makes up roughly a third of the Eurozone GDP and the remaining Eurozone countries denoting the core and the overall Eurozone constituting roughly 20 percent of world GDP.

\section{Results}

Figure 1 compares the effects of the fiscal devaluation enacted in the periphery for the 3-country model with that of the 2-country setting of EGTV. The peak output, consumption and trade balance increases in the periphery country rise from $1.21 \%, 0.73 \%$ and $0.27 \%$ of GDP to $1.33 \%, 0.79 \%$ and $0.3 \%$ of GDP respectively. The fiscal devaluation thus serves as an even better tool to stimulate output and consumption while the trade effect is a bit larger when the third country is included. The finding of EGTV with respect to the periphery is thus reinforced. At the same time the initial output contraction observed in the core in the 2-country setting turns into a small boom with an initial peak of $0.13 \%$ lasting for seven quarters in the 3-country setting. The increase in consumption is mitigated but this is more than offset by a deterioration of the trade balance that is $70 \%$ smaller $(-0.043 \%$ instead of $0.141 \%)$. The inclusion of a third country thus serves to cushion the $\mathrm{MU}$ core from this policy and hence overturns the finding of EGTV that the spillover effects to the core constitute a cost of fiscal devaluations to the MU. ${ }^{3}$

The reason for these effects are as follows: The periphery benefits from being a relatively smaller country in a 3-country world than in a 2-country world so that the foreign price reaction will be smaller and, c.p., a given fall in domestic goods prices will deteriorate the terms of trade more, boost net exports more and thereby generate a bigger wealth effect raising consumption even more. The core country benefits from a deterioration of its terms of trade vis-à-vis the rest of the world because of a nominal depreciation of the exchange rate boosting exports and thereby countering the fall in exports to the MU periphery. This increases hours worked, nominal wages and inflation so that the long-run

\footnotetext{
${ }^{3} \mathrm{~A}$ brief discussion on the sensitivity of results w.r.t. key parameters is presented in the appendix. If the Armington elasticity is 2 (1), we find a decrease (increase) in the core's output in a 2-country setup. Our choice of setting this parameter to 2 is motivated by recent empirical studies (Feenstra et al. 2017 and Imbs and M ejean 2015) suggesting values that are even higher than 2; by the empirical behavior of the trade balance and the terms of trade that our model is able to replicate; and because EGTV use it.
} 
real rate of interest falls less and consumption rises less. But the effect on trade is larger than the effect on consumption so that output rises while it contracts in the 2-country setting.
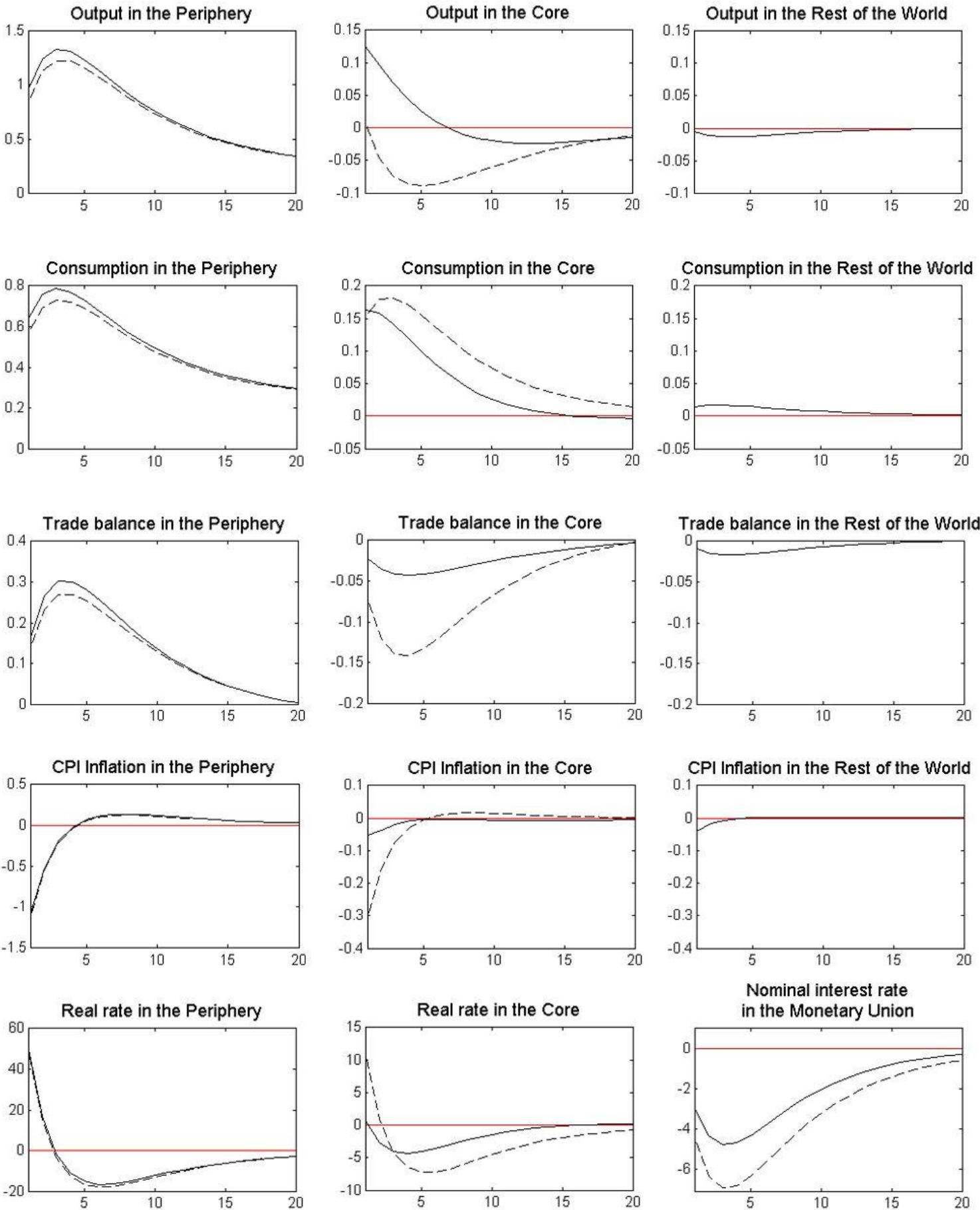

Nominal interest rate in the Monetary Union

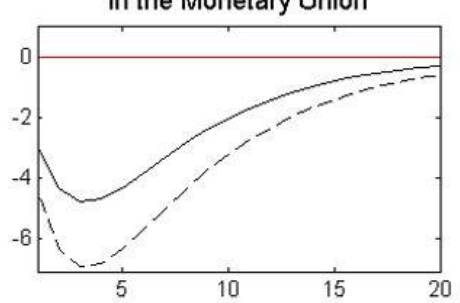

Terms of Trade: Periphery to Core

Terms of Trade: Periphery to Rest of the World
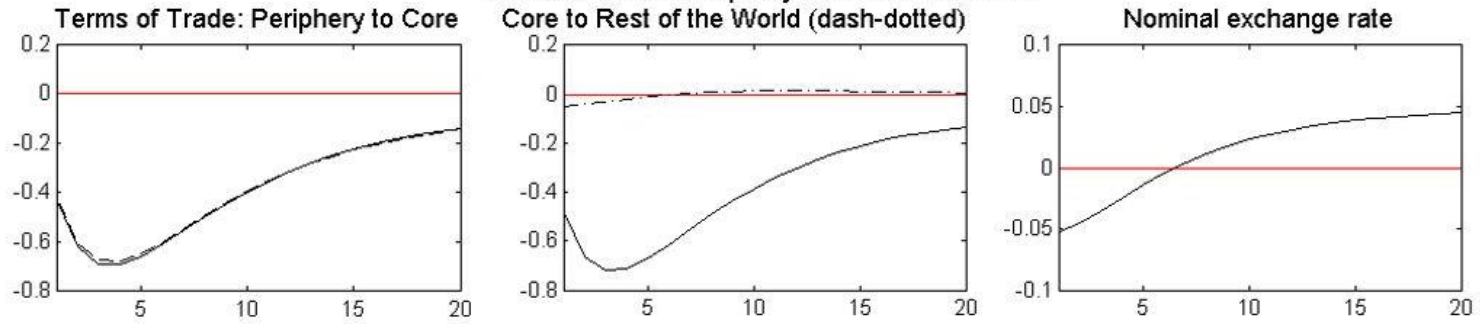


\section{Figure 1: Impulse responses to a fiscal devaluation in the periphery}

Note: Dashed lines appertain to the 2-country model, solid lines to the 3-country model. Inflation rates are annualized and expressed in percentage points. Interest rates are expressed in annualized basis point deviations. Deviations of trade balances are expressed in percentage of steady state output. For all other variables we report percentage deviations from their steady state values.

The deflation generated in the $\mathrm{MU}$ is exported to the rest of the world and with it the loose monetary policy stance. Rest of the world consumption rises but output contracts slightly.

\section{Conclusion}

We have shown that the inclusion of a third country into an otherwise standard model of a MU with two member countries changes the effects of a fiscal devaluation in an important way: It strengthens the stimulus in the economy that implements the fiscal devaluation and, more importantly, turns a recession into a small boom in the second MU member country. The policy is thus costless with respect to output.

\section{References:}

Bank of Portugal, 2011. The Impact of a Tax Change Aimed at Increasing the External Competitiveness of the Portuguese Economy. Economic Bulletin, 17, 39-42.

Boscá, J. E., Doménech, R., and Ferri, J., 2012. Fiscal Devaluations in EMU. BBVA WP 1211.

Calvo, G. A., 1983. Staggered Prices in a Utility-maximizing Framework. Journal of M onetary Economics, 12, 3, 383-398. https://doi.org/10.1016/0304-3932(83)90060-0

Centraal Planbureau (CPB) and CAPP, 2013. Study on the Impacts of Fiscal Devaluation. European Commission Taxation Papers (WP 36-2013).

de M ooij, R., and Keen, M., 2013. 'Fiscal Devaluation' and Fiscal Consolidation: The VAT in Troubled Times, in: Fiscal Policy after the Financial Crisis, ed. by A. Alesina, F. Giavazzi (Chicago: University of Chicago Press), 443-485.

Engler, P., Ganelli, G., Tervala, J., Voigts, S., 2017. Fiscal Devaluation in a Monetary Union. IM F Economic Review, 65, 241-273. https://doi.org/10.1057/s41308-016-0002-4

Erceg, C., Henderson, D., and Levin, A., 2000. Optimal M onetary Policy with Staggered Wage and Price Contracts. Journal of M onetary Economics, 46, 281-313. https:// doi.org/10.1016/S03043932(00)00028-3

Farhi, E., Gopinath, G., and Itskhoki, 0., 2014. Fiscal Devaluations. Review of Economic Studies, 81, 2, 725-760. https://doi.org/10.1093/restud/rdt036 
Feenstra, R., Luck, P., Obstfeld, M. and Russ, K., 2017. In Search of the Armington Elasticity. Review of Economic Studies, forthcoming. https://doi.org/10.1162/REST_a_00696

Gomes, S., Jacquinot, P. and Pisani, M., 2016. Fiscal Devaluation in the Euro Area: A M odel-Based Analysis. Economic M odelling, 52, 58-70. https://doi.org/10.1016/j.econmod.2015.06.019

Hohberger, S., and Kraus, L., 2016. Is Fiscal Devaluation Welfare Enhancing? Economic M odelling, 58, 512-522. https://doi.org/10.1016/j.econmod.2016.03.010

Imbs, J. and M ejean, I. 2015. Elasticity Optimism. American Economic Journal: M acroeconomics, 7, 43-83. https://doi.org/10.1257/mac.20130231

Lipinska, A., and von Thadden, L., 2012. On the (In)Effectiveness of Fiscal Devaluations in a M onetary Union. Board of Governors of the Federal Reserve System: Finance and Economics Discussion Series 2012-71. http:// dx.doi.org/10.2139/ssrn.2195201 